\title{
Novel Cell Death-Inducing Elicitors from Phytophthora palmivora Promote Infection on Hevea brasiliensis
}

\author{
Sittiporn Pettongkhao and Nunta Churngchow ${ }^{\dagger}$ \\ Department of Biochemistry, Faculty of Science, Prince of Songkla University, Hat-Yai, Songkhla 90112, Thailand \\ Accepted for publication 24 June 2019.
}

ABSTRACT

\begin{abstract}
Elicitors play an important role in plant and pathogen interactions. The discovery of new elicitors and their effects on plant defense responses is significant and challenging. In this study, we investigated novel elicitors from Phytophthora palmivora and their effects on plant defenses. A crude elicitor isolated by ethanol precipitation from culture filtrates of $P$. palmivora induced cell death in tobacco leaves. When tobacco leaves were infiltrated with this cell death-inducing elicitor, the accumulations of $\mathrm{H}_{2} \mathrm{O}_{2}$, salicylic acid (SA), scopoletin (Scp), and abscisic acid (ABA) were detected. Accumulations of SA, Scp, and ABA were also induced in rubber tree leaves. $P$. palmivora infection significantly increased in rubber tree leaves pretreated with the elicitor and cotreated with the elicitor and zoospores of $P$. palmivora. This elicitor can be described as compound elicitor because Fourier-transform infrared spectroscopy revealed that it consisted of both polysaccharide and protein. We also
\end{abstract}

found that the cell death effect caused by this compound elicitor was completely neutralized by Proteinase K. The compound elicitor was composed of four fractions which were beta-glucan, high-molecularweight glycoprotein, broad-molecular-weight glycoprotein and 42-kDa protein. Interestingly, the broad-molecular-weight glycoprotein caused the highest level of cell death in tobacco leaves, while the beta-glucan had no effect. The high-molecular-weight glycoprotein, broad-molecularweight glycoprotein and $42-\mathrm{kDa}$ protein fractions not only caused cell death in tobacco leaves but also induced high levels of SA accumulation. Furthermore, these three fractions clearly promoted $P$. palmivora infection of rubber tree leaves.

Keywords: 42-kDa protein, beta-glucan, cell death-inducing elicitor, glycoprotein, Phytophthora palmivora
Phytophthora palmivora is a hemibiotrophic pathogen. It can survive in dead tissue and acts as a necrotrophic pathogen. At the beginning of infection, it commonly grows as a biotroph and then switches to a necrotroph at later stages of infection. P. palmivora is classified among the oomycetes, which have characteristics distinct from the true fungi. Oomycete cell wall mainly consists of beta-1,3glucan, whereas the fungal cell wall is chitin (Werner et al. 2002; Latijnhouwers et al. 2003). In Thailand, P. palmivora causes stem rot in both the durian tree (Durio zibethinus) and the rubber tree (Hevea brasiliensis), with resultant crop losses.

Elicitors containing a variety of molecules are able to activate defense responses in host plants. Because elicitors are structurally conserved components, they are mostly classified as pathogenassociated molecular patterns (PAMPs). Reported biologically active elicitors produced by Phytophthora spp. include the oligopeptide 13 amino acid (Pep-13) within cell wall glycoprotein (GP42) of P. sojae (Brunner et al. 2002; Hahlbrock et al. 1995; Nürnberger et al. 1994;), the OPEL protein encoded by the OPEL gene (Chang et al. 2015) and the 34-kDa glycoprotein elicitor (CBEL) (Gaulin et al. 2006; Mateos et al. 1997) of P. parasitica. A new $75-\mathrm{kDa}$ protein and elicitin $(10 \mathrm{kDa})$ have been reported for $P$. palmivora. These proteins induce scopoletin (Scp), a plant phytoalexin, and total phenolic compound accumulations in the cell suspension of $H$. brasiliensis (Churngchow and Rattarasarn 2000; Dutsadee and Nunta 2008).

†Corresponding author: N. Churngchow; nunta.c@psu.ac.th

Funding: This study was supported by the Excellent Scholarships in Biochemistry, Department of Biochemistry, Faculty of Science, Prince of Songkla University, Thailand; the Graduate School of Prince of Songkla University, Thailand; and The Royal Golden Jubilee Graduated Program (RGJ-PHD) through the Thailand Research Fund (TRF) to S. Pettongkhao (PHD/0067/2556).

The author(s) declare no conflict of interest.

(c) 2019 The American Phytopathological Society
An important process in plant defenses against pathogens is hypersensitive response (HR) cell death. It is induced by accumulations of $\mathrm{O}_{2}^{-}$and $\mathrm{H}_{2} \mathrm{O}_{2}$, which finally trigger a protein kinase-mediated cell death process similar to program cell death (PCD) (Levine et al. 1996; Mehdy 1994). Accumulation of $\mathrm{H}_{2} \mathrm{O}_{2}$ inhibits the growth of biotrophic pathogens (Thordal-Christensen et al. 1997), whereas production of $\mathrm{H}_{2} \mathrm{O}_{2}$ promotes the growth of necrotrophic pathogens (Govrin and Levine 2000). Lee and Rose (2010) suggested that the hemibiotrophic pathogen $P$. infestans facilitates the development of infection by secreting a cell death suppressor during its biotrophic phase and producing cell death inducers in its necrotrophic phase. The virulence of Botrytis cinerea, a necrotrophic pathogen, is conducted by a number of lytic enzymes, toxins, and high levels of reactive oxygen species and necrosis-inducing factors (Choquer et al. 2007; van Kan 2006). Govrin and Levine (2000) concluded that $B$. cinerea induces the accumulation of $\mathrm{H}_{2} \mathrm{O}_{2}$ to kill Arabidopsis thaliana cells and facilitate its invasion. HR cell death resists biotroph infection by disconnecting nutrient supplies resulting in limiting pathogen growth, however, it may provide growth substrates for invasive necrotrophs (Govrin and Levine 2000). Hemibiotrophs, meanwhile, establish a biotrophic stage within the plant, kill host cells, and then switch to a necrotrophic fungal phase (Horbach et al. 2011).

HR cell death is activated by the salicylic acid (SA)-signaling pathway. Torres et al. (2005) and Lu et al. (2009) showed that a high level of SA facilitated PCD in A. thaliana. SA and jasmonic acid (JA) are secondary messengers involved in PAMP-triggered immunity and effector-triggered immunity (Bent and Mackey 2007; van Loon et al. 2006). The SA-signaling pathway activated by biotrophs can suppress the JA-signaling pathway which is involved in blocking necrotrophic pathogen infection (Koornneef et al. 2008; Pieterse et al. 2012; Spoel et al. 2007). PCD is the effective defense against biotrophic pathogens which is regulated by the SAdependent pathway. On the other hand, necrotrophic pathogens benefit from host cell death and therefore are not restricted by the SA-dependent pathway but are controlled by the JA-signaling 
pathway (Glazebrook 2005). Some pathogens can mimic signaling pathways to suppress defense responses. For example, B. cinerea produces a beta-glucan elicitor that activates the SA-signaling pathway and suppresses the JA-signaling pathway (El Oirdi et al. 2011). The phytotoxin coronatine, a JA mimic produced by the biotrophic pathogen Pseudomonas syringae, promotes its infection by suppressing the SA-signaling pathway (Brooks et al. 2005; Cui et al. 2005).

Cell death and SA inductions are benefits for necrotrophic infections (Glazebrook 2005; Govrin and Levine 2000). Based on the nature of $P$. palmivora, it switches into necrotroph; consequently, cell death- and SA-inducing elicitors could promote $P$. palmivora infection. Like a glycoside hydrolase family 12 (GH12) protein, XEG1 produced by the soybean pathogen $P$. sojae exhibits xyloglucanase and beta-glucanase activity, and can act as a PAMP. It induces cell death in Nicotiana benthamiana and plays an important role as a virulence factor during $P$. sojae infection. After the XEG1 in $P$. sojae was silenced, its virulence was reduced (Ma et al. 2015). $B$. cinerea produces a cell death-inducing elicitor that promotes the gray mold disease on A. thaliana leaves (Govrin et al. 2006) and a beta-glucan elicitor that promotes its infection of tomato plants by activating the SA-signaling pathway and suppressing the JA-signaling pathway (El Oirdi et al. 2011). Kliebenstein and Rowe (2008) suggested that the HR cell death caused by biotrophs could increase necrotrophic infection after being inoculated in the same area. P. palmivora acts as a biotroph and then switches to a necrotroph. If the cell death response is activated at the biotrophic phase of $P$. palmivora, the infection cannot be resisted; consequently, activated cell death may promote its infection in the necrotrophic phase.

However, the effects of cell death-inducing elicitors of $P$. palmivora have rarely been reported. To identify new elicitors and their effects on plant defense response, we isolated a crude elicitor from culture filtrate of $P$. palmivora. The crude elicitor showed cell death-inducing activity in tobacco leaves and promoted $P$. palmivora infection in rubber tree leaves. We fractionated the crude cell death-inducing elicitor into four fractions, beta-glucan (F1), high-molecular-weight glycoprotein (F2), broad-molecularweight glycoprotein (F3), and 42-kDa protein (F4). F2, F3, and F4 fractions were novel compounds and no one has reported their effect before. They induced SA accumulation and cell death, but the betaglucan (F1) induced SA accumulation without cell death. Interestingly, the high-molecular-weight glycoprotein, broad-molecular-weight glycoprotein, and 42-kDa protein significantly promoted $P$. palmivora infection of rubber tree leaves.

\section{MATERIALS AND METHODS}

Pathogen and plants. $P$. palmivora isolated from rubber tree leaves was generously given by the Songkhla Rubber Research Center, Songkhla, Thailand. The $P$. palmivora mycelium was grown on potato dextrose agar (PDA) at $25^{\circ} \mathrm{C}$ for 1 week. PDA plugs containing $P$. palmivora were cut with a $5 \mathrm{~mm}$ diameter cork borer and transferred onto V8 juice agar for 1 week. To trigger the release of zoospores from sporangia, 1-week-old P. palmivora on V8 juice agar was layered with sterile distilled water, further incubated at $4^{\circ} \mathrm{C}$ for $15 \mathrm{~min}$, and then shaken at $25^{\circ} \mathrm{C}$ for $15 \mathrm{~min}$. Petroff Hausser (Boeco, Germany), a cell counter, was utilized to count zoospores under a light microscope. To prepare the elicitor, 1-week-old P. palmivora on V8 juice agar was cut with a cork borer, transferred into Henninger medium (Henniger 1963) and cultured in an incubator at $25^{\circ} \mathrm{C}$, with shaking at $100 \mathrm{rpm}$ for 14 days. The culture filtrate was drained through Whatman filter paper (No. 1).

Rubber plant seedlings of cultivar RRIM600 at the developmental B2C stage and 8-week-old tobacco plants (Nicotiana tabacum) were maintained in a temperature-controlled room with photoperiod regulation $\left(12 \mathrm{~h}\right.$ light: $12 \mathrm{~h}$ dark: $\left.25^{\circ} \mathrm{C}\right)$.

Elicitor isolation and fractionation. Culture filtrate $(100 \mathrm{ml})$ was precipitated with 3 volumes of cool $80 \%$ ethanol and then the pellet was collected by centrifugation at $10,000 \mathrm{rpm}$, for $10 \mathrm{~min}$ at $4^{\circ} \mathrm{C}$. The pellet was redissolved with distilled water and subsequently fractionated once for $5 \mathrm{~min}$ by the Sevage method (Chloroform: $n$-buthanol $=4: 1$ ) to remove proteins. To obtain the crude elicitor, the aqueous phase was collected, dialyzed, and lyophilized.

The obtained crude elicitor was dissolved in $20 \mathrm{mM}$ Tris- $\mathrm{HCl}$ at $\mathrm{pH} 7.5$ to achieve a final concentration of $0.0125 \mathrm{mg} / \mathrm{ml}$. A $25-\mathrm{ml}$ aliquot of the elicitor solution was loaded into a DEAE-Sepharose column (GE Healthcare, U.S.A., $25 \mathrm{ml}$ gel volume) at a static flow rate of $0.75 \mathrm{ml} / \mathrm{min}$. After collecting 10 tubes $(2.5 \mathrm{ml}$ of each) of the unbound component (F1), the column was washed with $25 \mathrm{ml}$ of $20 \mathrm{mM}$ Tris- $\mathrm{HCl}, \mathrm{pH} 7.5$, and then eluted with $25 \mathrm{ml}$ of $20 \mathrm{mM}$ Tris$\mathrm{HCl}, \mathrm{pH} 7.5$, containing $0.1 \mathrm{M} \mathrm{NaCl}$. Ten tubes of a second fraction (F2) were collected. The elution was repeated for the third (F3) and fourth (F4) fractions, eluting respectively with 0.15 and $0.3 \mathrm{M} \mathrm{NaCl}$ in $25 \mathrm{ml}$ of $20 \mathrm{mM}$ Tris-HCl, pH 7.5. Ten tubes of the third (F3) and fourth $(\mathrm{F} 4)$ fractions were collected. Every tube was measured using the phenol-sulfuric acid method for polysaccharide detection and with absorption at $280 \mathrm{~nm}$ for protein content. The target fractions with a high polysaccharide or protein content were pooled and checked for purity by sodium dodecyl sulfate-polyacrylamide gel electrophoresis (SDS-PAGE). For further utilization, the elicitors were desalted in a PD-10 column (GE Healthcare) and then lyophilized.

For size exclusion chromatography, Sephadex-G75 (GE Healthcare) was utilized to purify the $42-\mathrm{kDa}$ protein. Briefly, lyophilized powder of the F4 fraction was redissolved with $20 \mathrm{mM}$ Tris- $\mathrm{HCl}$, $\mathrm{pH} 7.5$, buffer. The elicitor solution $(250 \mu \mathrm{l})$ was loaded into the Sephadex-G75 column $(11 \times 520 \mathrm{~mm}, 49 \mathrm{ml}$ of gel volume $)$ using the invariable flow rate at $0.15 \mathrm{ml} / \mathrm{min}$. Each tube $(0.75 \mathrm{ml})$ was collected for 65 tubes. One hundred microliters of each separated tube was infiltrated into tobacco leaves to detect the cell death induction. Fractions causing cell death were collected and further analyzed by SDS-PAGE. Three replicates were performed for Sephadex-G75 purification.

Cell death induction in tobacco leaves. Crude elicitor solution at a concentration of $250 \mu \mathrm{g} / \mathrm{ml}$ was infiltrated into tobacco leaves. After $24 \mathrm{~h}$, visual evidence of cell death was photographed with a digital camera (Canon EOS 1100D). Sterile distilled water was the control.

After desalting and lyophilizing, F1, F2, F3, and F4 were redissolved in $1 \mathrm{ml}$ of sterile distilled water and $100 \mu \mathrm{l}$ of each solution was infiltrated into tobacco leaves to observe for cell death induction. Five independent biological replicates were performed.

Histochemical staining on tobacco leaves. Cell death was monitored at $12 \mathrm{~h}$ postinfiltration. At this time point, cell death on treated tobacco leaves was not visible, so visualization was attempted with Trypan blue staining following a method adapted from Leite et al. (1999). At the designated time points, the tobacco leaves were placed in $0.1 \%$ (vol/vol) Triton X-100 for $10 \mathrm{~min}$ and transferred into a $0.4 \%$ (wt/vol) Trypan blue solution (Sigma Aldrich, U.S.A.) for $30 \mathrm{~min}$. The unbound dye was rinsed out with sterile distilled water and the leaves were digitally photographed under light microscopy.

To determine the localization of hydrogen peroxide $\left(\mathrm{H}_{2} \mathrm{O}_{2}\right)$ at $12 \mathrm{~h}$ postinfiltration, the tobacco leaves were stained with $3,3^{\prime}$ diaminobenzidine (DAB) (Sigma Aldrich) according to a procedure adapted from Thordal-Christensen et al. (1997). Briefly, the leaves were immersed in $0.1 \%$ (vol/vol) Triton X-100 for $20 \mathrm{~s}$, placed in $1 \mathrm{mg} / \mathrm{ml}$ (wt/vol) DAB, and incubated at room temperature. After 8 $\mathrm{h}$, the leaves were cleared by boiling for $30 \mathrm{~min}$ in $95 \%$ ethanol to stop the reaction and to remove chlorophyll from the leaf tissue. Five independent biological replicates were performed.

High performance liquid chromatography (HPLC) analysis. Rubber tree and tobacco leaves were respectively sprayed and infiltrated with the elicitor and then collected at designated time points to measure levels of SA, Scp, and ABA by 
HPLC. The samples were extracted according to the method of Ederli et al. (2011) with modification. The treated leaves $(0.5 \mathrm{~g})$ were ground to a fine powder in a mortar with liquid nitrogen and mixed with $750 \mu \mathrm{l}$ of $90 \% \mathrm{MeOH}$. The suspensions were transferred into 1.5-ml Eppendorf tubes, centrifuged at 12,000 rpm for $5 \mathrm{~min}$, and the supernatants were collected. Pellets were resuspended with $500 \mu \mathrm{l}$ of $90 \% \mathrm{MeOH}$ and centrifuged again at 12,000 rpm for $5 \mathrm{~min}$. The supernatants were pooled and added with $50 \%$ (wt/vol) trichloroacetic acid to a final concentration of 5\% (wt/vol) and then filtered through a $0.2 \mu$ m nylon membrane. The extracted samples were analyzed using HPLC (Agilent series 1100, Waldbronn, Germany) with Eclipse XDB-C18 column (ZORBAX, $4.6 \times$ $150 \mathrm{~mm}, 5$ micron particle size). The mobile phases consisted of two solutions, $0.1 \%$ formic acid and acetonitrile (ACN), used in gradient elution system, increasing the percentage of ACN. Briefly, we used static $20 \%$ ACN from 0 to $2 \mathrm{~min}$; after $2 \mathrm{~min}$, the ACN content was increased from 20 to $40 \%$ until $8.50 \mathrm{~min}$; after $8.50 \mathrm{~min}$, we used static $40 \%$ ACN until $10 \mathrm{~min}$ and then increased ACN from 40 to $60 \%$ until 13 min. A diode array detector was used to detect $\mathrm{ABA}$ at $254 \mathrm{~nm}$ and fluorescence detectors were used to analyze the levels of Scp (337 nm Ex and $425 \mathrm{~nm} \mathrm{Em}$ ) and SA (294 nm EX, $426 \mathrm{~nm}$ EM). Three independent biological replicates were performed.

Functional identification. Infrared (IR) spectra of the crude elicitor and F1 fraction were produced using Fourier-transform infrared (FTIR) spectroscopy. One gram of each was mixed with spectroscopic grade $\mathrm{KBr}$ powder, dispersed in a $\mathrm{KBr}$ disc, and then pressed into $1 \mathrm{~mm}$ pellets for FTIR measurement in a wave range from 600 to $4,000 \mathrm{~cm}^{-1}$ (Bruker: Vertex70).

Gel staining. After SDS-PAGE, gels were stained with a silver nitrate staining kit (GE Healthcare, Bio-Sciences) according to the manufacturer's protocol for protein detection. Glycoprotein was stained by periodic acid-Schiff staining (Zacharius et al. 1969). Briefly, after fixing in 7.5\% (vol/vol) acetic acid for $1 \mathrm{~h}$, the gel was immersed in $1 \%$ (vol/vol) periodic acid for $45 \mathrm{~min}$ at $4{ }^{\circ} \mathrm{C}$ in darkness, washed in $7.5 \%$ acetic acid for $10 \mathrm{~min}$ (six times) then stained with the periodic acid-Schiff reagent for $1 \mathrm{~h}$ at $4^{\circ} \mathrm{C}$ in the dark. Finally, the gel was washed with a $0.5 \%$ (wt/vol) sodium metabisulfite solution.

Cell death neutralization. A crude elicitor aliquot of $50 \mu \mathrm{g}$ in $1 \mathrm{ml}$ of $100 \mathrm{mM}$ sodium acetate buffer at $\mathrm{pH} 5.0$ was digested with $100 \mu \mathrm{l}$ of beta-1,3-glucanase $(0.6 \mathrm{U} / \mathrm{ml})$ for $8 \mathrm{~h}$ at $20^{\circ} \mathrm{C}$. After centrifugation for $5 \mathrm{~min}$ at $12,000 \mathrm{rpm}$, the digested solution was infiltrated into tobacco leaves. In addition, $500 \mu \mathrm{g}$ of the crude elicitor in $1 \mathrm{ml}$ of $20 \mathrm{mM}$ Tris- $\mathrm{HCl}, \mathrm{pH} 7.5$, was treated with $20 \mu \mathrm{g}$ of Proteinase $\mathrm{K}$ for $30 \mathrm{~min}$ at $37^{\circ} \mathrm{C}$, centrifuged for $5 \mathrm{~min}$ at $12,000 \mathrm{rpm}$, and then infiltrated into tobacco leaves. Three independent biological replicates were performed.

Infection of rubber tree leaves by $\boldsymbol{P}$. palmivora. Initially, a droplet method was used to apply crude elicitor to rubber tree leaves by cotreatment with zoospores of $P$. palmivora. The ventral side of the leaves was wetted with drops $(25 \mu \mathrm{l})$ of a mixture solution containing $1 \times 10^{4}$ zoospores $/ \mathrm{ml}$ of $P$. palmivora in crude elicitor at a concentration of $250 \mu \mathrm{g} / \mathrm{ml}$. The leaves were monitored for disease development at 5 days posttreatment. A mixture solution containing $1 \times 10^{4}$ zoospores $/ \mathrm{ml}$ of $P$. palmivora in sterile distilled water was used as the control.

Exposing rubber tree leaves to infection by spraying required pretreatment of the leaves with $250 \mu \mathrm{g} / \mathrm{ml}$ of crude elicitor solution, which was sprayed onto the leaves for $24 \mathrm{~h}$. After that time, the treated leaves were sprayed with $1 \times 10^{4}$ zoospores $/ \mathrm{ml}$ of P. palmivora. Besides this pretreatment spraying method, rubber tree leaves were also cosprayed with crude elicitor, at $250 \mu \mathrm{g} / \mathrm{ml}$, and $P$. palmivora zoospores at $1 \times 10^{4}$ zoospores $/ \mathrm{ml}$. The severity of infection was evaluated according to the method described by Yang et al. (1996). Five grades of symptom were taken into consideration. If no infection spot was visible, the leaf was classified as grade 0 , no symptom; grade 1, slight symptoms (1 to 20 infection spots/leaf); grade 2, medium disfigurement (21 to 40 infection spots/leaf); grade 3, rather serious disfigurement (41 to 60 infection spots/leaf); and grade 4 , very serious symptoms (more than 60 infection spots/ leaf). The disease severity index was calculated using the following formula:

$$
\begin{aligned}
& \text { Disease severity index }(\text { DSI })= \\
& \frac{\sum(\text { disease grade } \times \text { number of leaves in each grade } \times 100)}{(\text { total number of leaves } \times \text { highest disease grade })}
\end{aligned}
$$

Three independent biological replicates were performed and each replicate consisted of 42 leaves. For testing disease induction by the F1, F2, F3, and F4 fractions, $100 \mu \mathrm{l}$ of elicitor solutions was mixed with $100 \mu \mathrm{l}$ of $P$. palmivora zoospores at a concentration of $2 \times 10^{4}$ zoospores $/ \mathrm{ml}$ and rubber tree leaves were wetted with drops $(20 \mu \mathrm{l})$ of the mixtures. Five days posttreatment, lesion diameters were measured. Four independent biological replicates were performed.

Statistical analysis. The presented values were mean value \pm standard error (SE) from the results of at least three independent biological replicates. SPSS Statistics 17.0 software was used to determine significance at $P \leq 0.05$ by one-way analysis of variance according to Duncan's multiple range tests. Pairwise comparisons with lower numbers of treatments were conducted according to Student's $t$ test at $P \leq 0.05$.

\section{RESULTS}

Isolation of cell death-inducing elicitor. Our goal was to identify a new cell death-inducing elicitor from the culture filtrate of P. palmivora, growing in Henninger medium (Henniger 1963), by ethanol precipitation. The obtained elicitor caused cell death on tobacco leaves at $24 \mathrm{~h}$ postinfiltration (Fig. 1A). This elicitor did not cause cell death in rubber tree leaves, either by the droplet or the spraying methods, but after making a wound in the leaf to facilitate diffusion into the cells, it could cause chlorotic cell death (Fig. 1B).

In tobacco leaves, cell death induced by this elicitor was not visible at $12 \mathrm{~h}$ postinfiltration. However, it could be observed after Trypan blue staining (Fig. 1C2). Cell death requires the accumulation of reactive oxygen species (ROS), $\mathrm{O}_{2}^{-}$, and $\mathrm{H}_{2} \mathrm{O}_{2}$ (Levine et al. 1996; Mehdy 1994). Interestingly, at $12 \mathrm{~h}$ postinfiltration, accumulation of $\mathrm{H}_{2} \mathrm{O}_{2}$ was detected using DAB staining method (Fig. 1C4). The results suggested that the obtained elicitor might cause cell death on tobacco leaves through the accumulation of $\mathrm{H}_{2} \mathrm{O}_{2}$.

Effects of the cell death-inducing elicitor. Tobacco leaves: Inductions of $S A, S c p$, and $A B A$. After infiltrating the crude elicitor into tobacco leaves, SA, Scp, and ABA levels were measured by HPLC. SA generally facilitates cell death in plants (Lu et al. 2009; Torres et al. 2005). The level of SA was significantly increased at $4 \mathrm{~h}$ postinfiltration compared with the control leaves and was continuously induced throughout $12 \mathrm{~h}$ (Fig. 2A). Scp, a tobacco phytoalexin, also gradually increased at $4 \mathrm{~h}$ postinfiltration and synthesized abundantly at $12 \mathrm{~h}$ (Fig. 2B). In a previous work, cell death initiated by wounding was significantly induced by ABA (Cui et al. 2013). Our results showed that the level of ABA was significantly increased at $12 \mathrm{~h}$, which correlated with the occurrence of cell death (Fig. 2C). These results indicated that our elicitor might induce cell death not only through $\mathrm{H}_{2} \mathrm{O}_{2}$ accumulation, but also through $\mathrm{SA}$ and ABA accumulations.

Rubber tree leaves: Induction of SA, Scp, and ABA. After spraying rubber tree leaves with a concentration of $250 \mu \mathrm{g} / \mathrm{ml}$ of the cell death-inducing elicitor, the levels of SA, Scp, and ABA were analyzed by HPLC. It was found that the SA level at $48 \mathrm{~h}$ posttreatment had significantly increased compared with the level in control leaves (Fig. 3A) and that the level of Scp had significantly increased at $24 \mathrm{~h}$ posttreatment and remained high until $96 \mathrm{~h}$ 
posttreatment (Fig. 3B). In addition, the level of ABA had significantly increased at 72 and $96 \mathrm{~h}$ posttreatment (Fig. 3C). These results indicated that our cell death-inducing elicitor increased SA, Scp, and ABA accumulations not only in tobacco leaves but also in rubber tree leaves.

Rubber tree leaves: Promotion of P. palmivora infection. To determine whether the cell death-inducing elicitor facilitated $P$. palmivora infection in rubber tree leaves, we performed cotreatments with $P$. palmivora zoospores and the cell deathinducing elicitor by both droplet and spraying methods. Infection from cotreatment by the droplet method was clearly more severe than it was in leaves coinfected with $P$. palmivora zoospores and sterile distilled water (Fig. 3D). After treatment by spraying, the infection levels were classified into five categories (Fig. 3E). Rubber tree leaves pretreated with the cell death-inducing elicitor and infected with $P$. palmivora showed a more severe level of infection than controls (Fig. 3F). In addition, the severity of the symptoms significantly increased after cotreatment with the cell death-inducing elicitor and P. palmivora zoospores (Fig. 3F). The results suggested that our cell death-inducing elicitor enhanced $P$. palmivora infection on rubber tree leaves.

Identification and characterization of the cell deathinducing elicitor. By FTIR and SDS-PAGE. Since this elicitor induced cell death and promoted $P$. palmivora infection, it merited

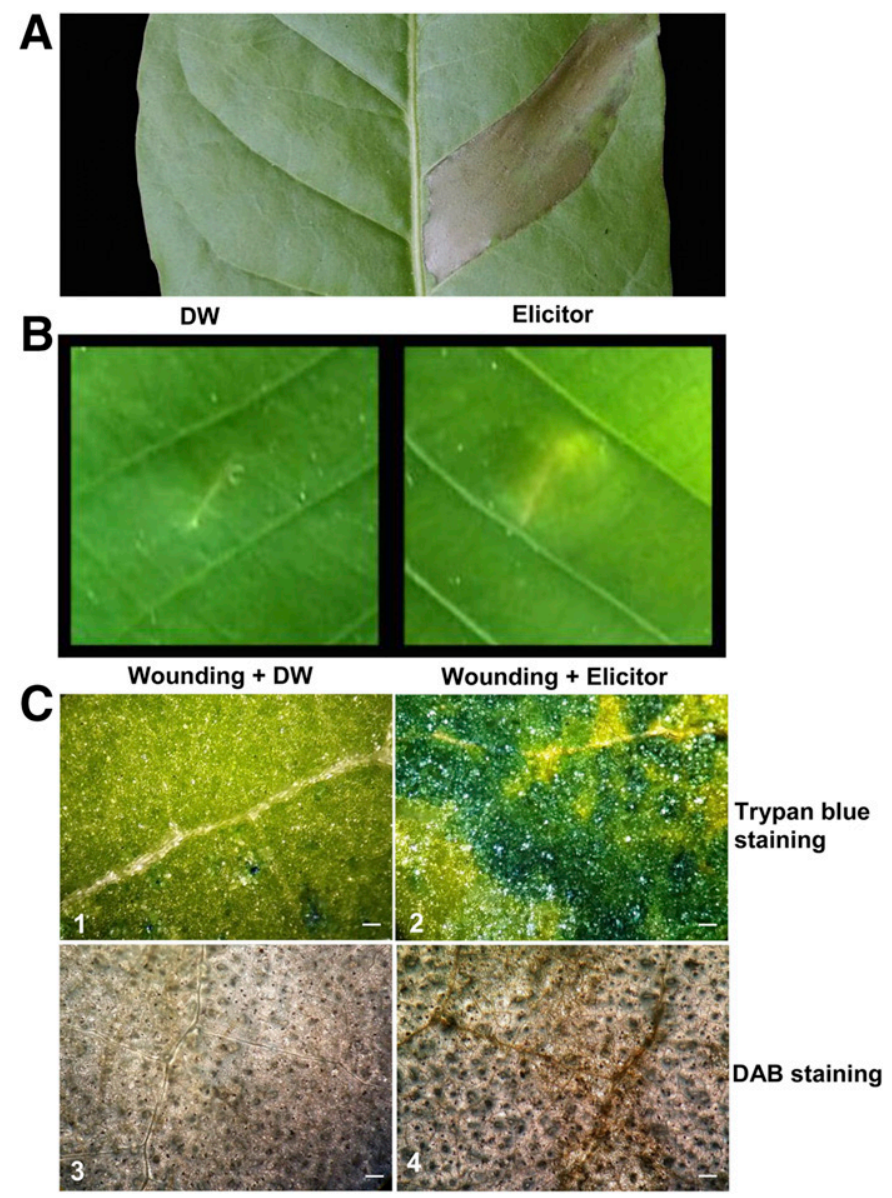

Fig. 1. A, Cell death induced by the crude elicitor on tobacco leaves at $24 \mathrm{~h}$ postinfiltration. B, The representatives of chlorotic cell death on wounded rubber tree leaves at 5 days after droplet method treatment with the cell deathinducing elicitor. $\mathbf{C}$, Trypan blue staining of infiltrated areas on tobacco leaves treated with sterile distilled water (C1) and elicitor solution at $250 \mu \mathrm{g} / \mathrm{ml}(\mathrm{C} 2)$, and DAB staining of infiltrated areas on tobacco leaves treated with sterile distilled water (C3) and elicitor solution at $250 \mu \mathrm{g} / \mathrm{ml}(\mathrm{C} 4)$ at $12 \mathrm{~h}$ postinfiltration. Images in $\mathrm{C}$ were photographed under a light microscope (scale bars $=200 \mu \mathrm{m}$ ). The pictures are representative of five independent biological replicates and all replicates showed the same results. further characterization. The FTIR spectrum of the cell deathinducing elicitor presented many absorption bands which were characteristic of polysaccharides (Fig. 4A). We detected a broad and strong absorption band at $3387 \mathrm{~cm}^{-1}$ and a band at $2927 \mathrm{~cm}^{-1}$. The bands near 3405 and $2930 \mathrm{~cm}^{-1}$ indicated stretching of the $\mathrm{OH}$ group and $\mathrm{CH}$ bond, respectively (Šandula et al. 1999). A strong and broad absorption band, detected between 950 and $1200 \mathrm{~cm}^{-1}$
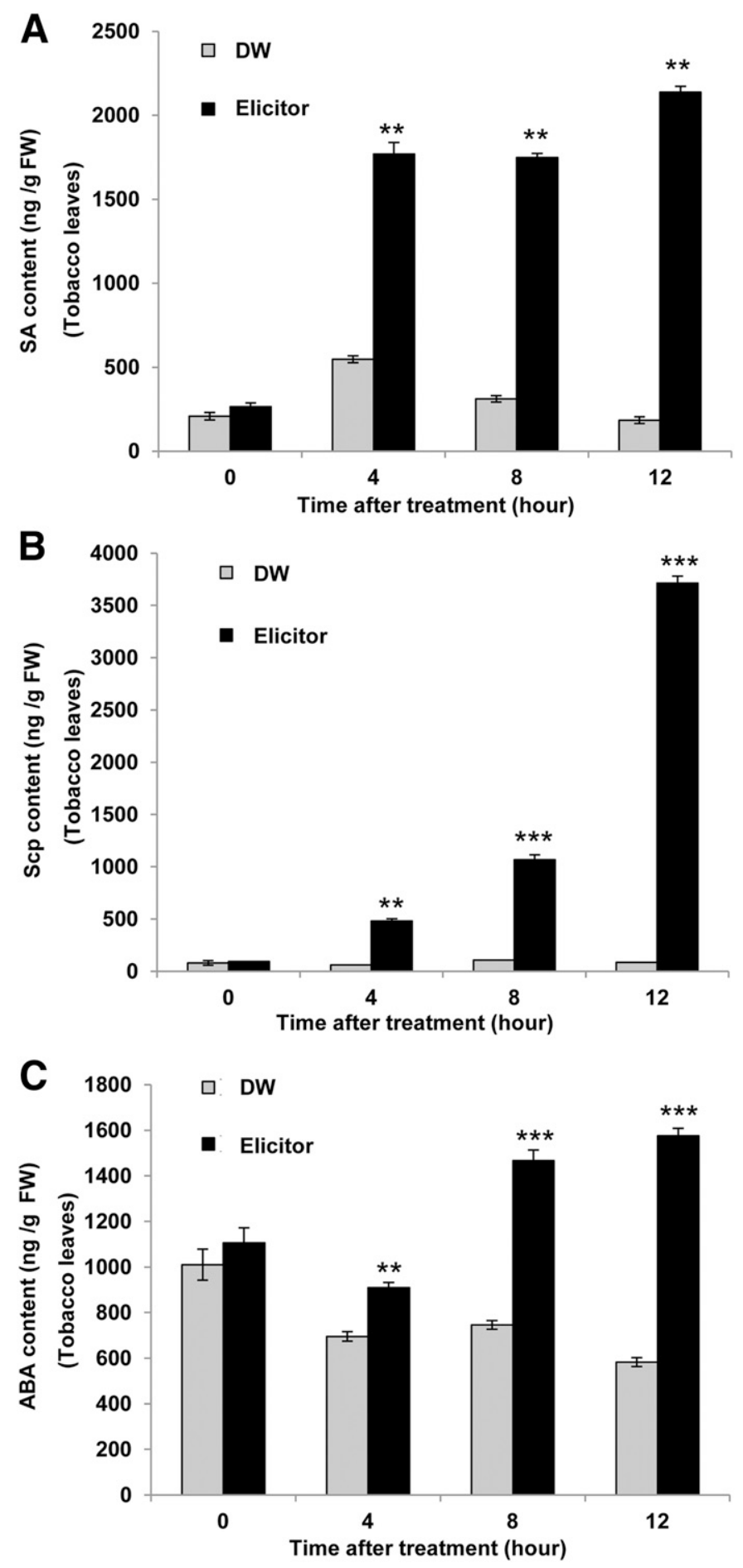

Fig. 2. High-performance liquid chromatography analysis of time-related concentrations of $\mathbf{A}$, salicylic acid (SA), B, scopoletin (Scp), and $\mathbf{C}$, and abscisic acid (ABA) in tobacco leaves after infiltration with the cell deathinducing elicitor and sterile distilled water (DW). Data bars are the means $( \pm \mathrm{SE})$ of three independent biological replicates. $* *$ and $* * *$ indicate statistically significant differences of cell death-inducing elicitor-treated tobacco leaves compared with sterile distilled water-treated tobacco leaves as a control ( $P \leq 0.05$ and 0.01 , respectively) determined by Student's $t$ test. 
was assigned to CO vibration (Šandula et al. 1999). The FTIR spectrum also showed absorption bands at 1546 and $1649 \mathrm{~cm}^{-1}$ (Fig. 4A), which were from amide $\mathrm{I}(\mathrm{C}=\mathrm{O})$ and amide $\mathrm{II}(\mathrm{NH})$ of proteins, respectively (Barth 2007; Belton et al. 1995). The spectrum indicated that the cell death-inducing elicitor consisted of polysaccharides and proteins. Furthermore, after SDS-PAGE and staining with silver nitrate, we observed many proteins. These results suggested that the cell death-inducing elicitor was a compound elicitor because it contained polysaccharide and protein. This point motivated us to fractionate the compound elicitor and to investigate which parts of it could cause cell death and promote $P$. palmivora infection.
A
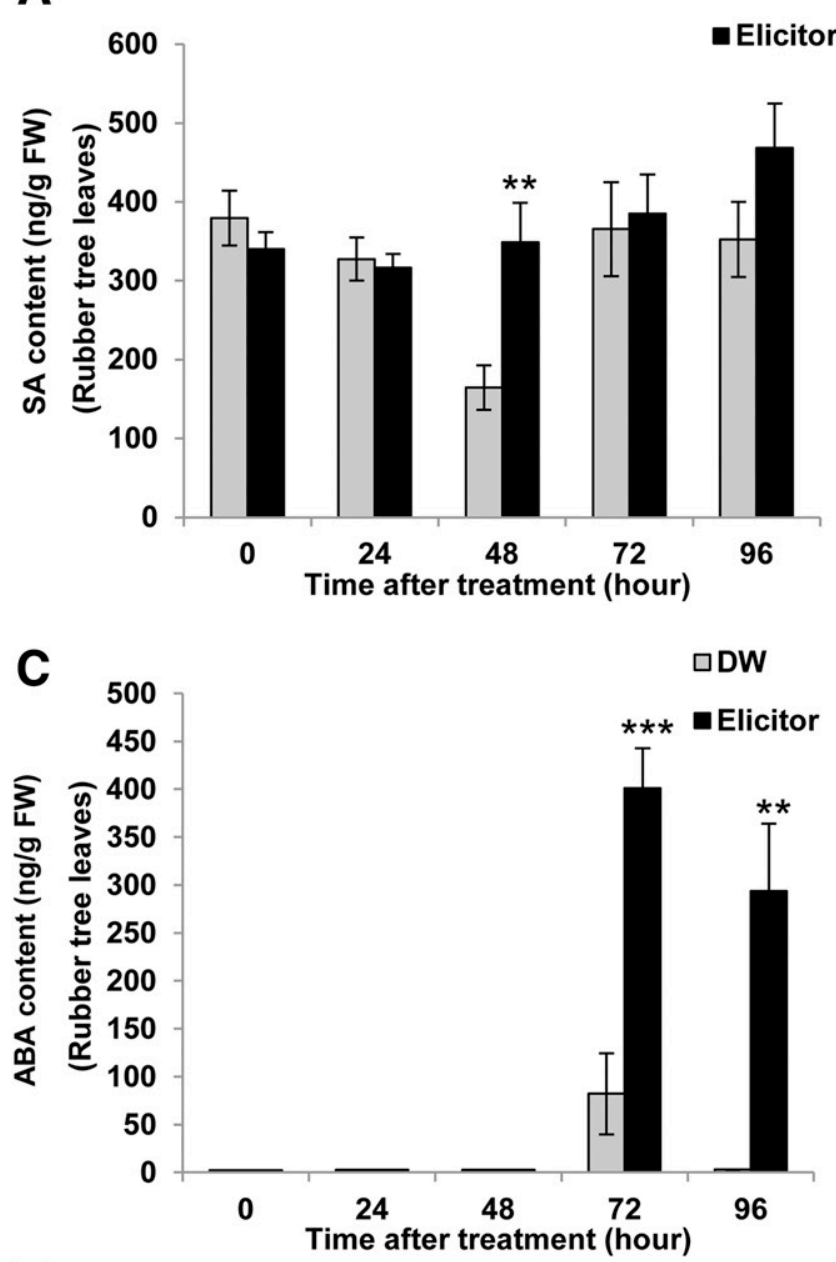

$\mathbf{E}$

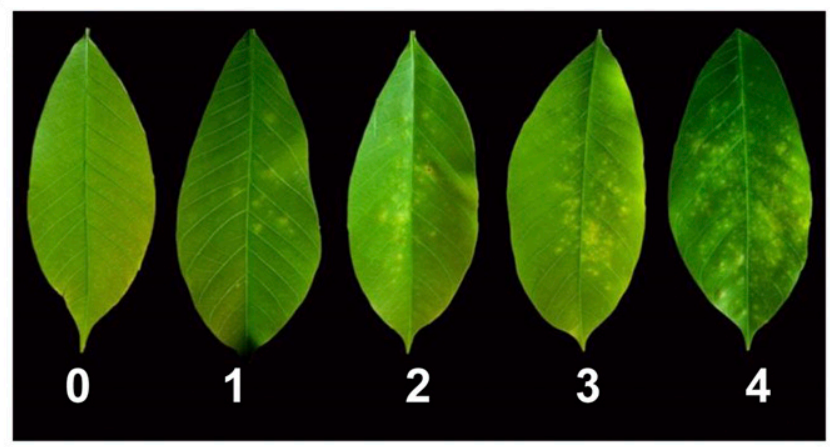

Infection levels

(Rubber tree leaves)
B

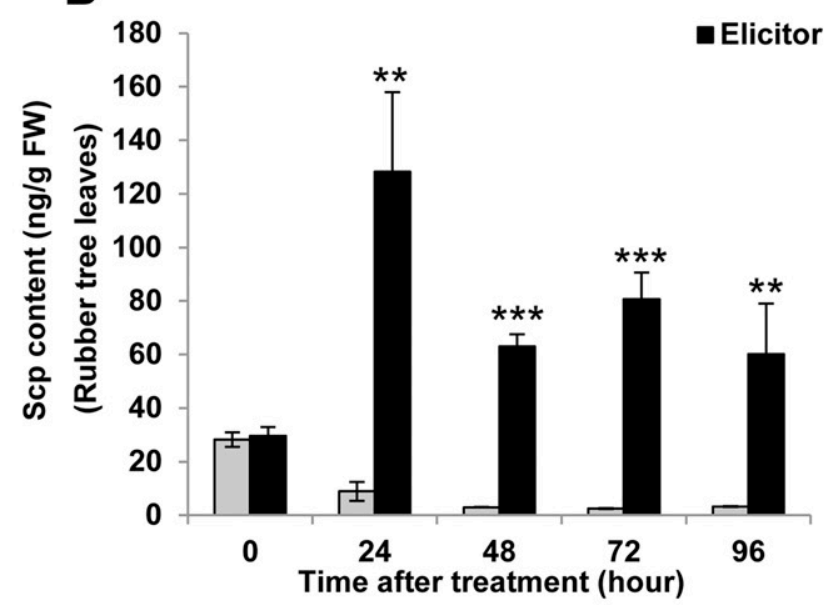

D

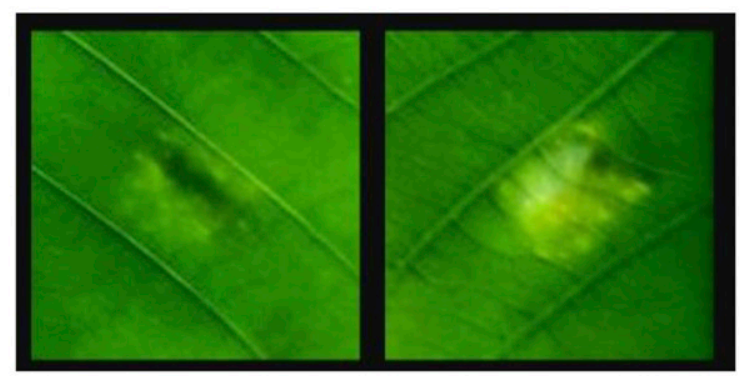

DW+ Zoospores

Elicitor + Zoospores

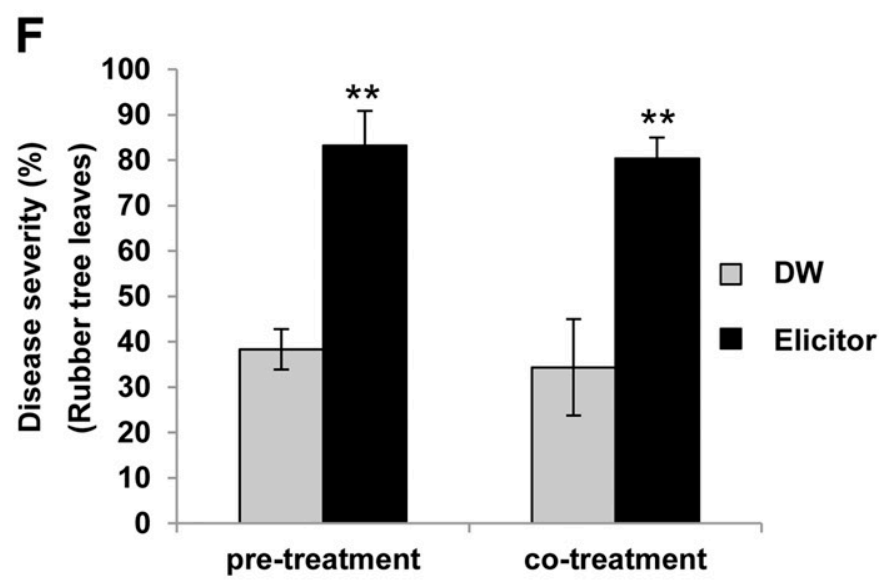

Fig. 3. High-performance liquid chromatography analysis of A, salicylic acid (SA), B, scopoletin (Scp), and $\mathbf{C}$, and abscisic acid (ABA) in rubber tree leaves after treatment with the cell death-inducing elicitor by spraying method. D, The representatives of disease symptom from five independent biological replicates caused by coinfection with cell death-inducing elicitor and Phytophthora palmivora by a droplet method at 5 days after infection and all replicates showed the same result. $\mathbf{E}$, Images of symptoms of $P$. palmivora infection on rubber tree leaves from spraying treatment were used to evaluate the disease severity index (level 0 to 4 ). F, The disease severity of $P$. palmivora infection on rubber tree leaves after pretreatment and cotreatment with the cell death-inducing elicitor using spraying method. Data bars are the means $( \pm \mathrm{SE})$ of three independent biological replicates. $* *$ and $* * *$ indicate statistically significant differences of cell death-inducing elicitortreated rubber tree leaves compared with sterile distilled water-treated rubber tree leaves as a control $(P \leq 0.05$ and 0.01 , respectively) determined by Student's $t$ test. 
By enzyme beta-1,3-glucanase and Proteinase K. The compound elicitor was digested with two enzymes, beta-1,3-glucanase for glucan degradation and Proteinase $\mathrm{K}$ for protein elimination. We found that Proteinase K completely neutralized cell death caused by the compound elicitor. In contrast, beta-1,3-glucanase did not inhibit cell death induction (Fig. 5). The results implied that the protein moiety in the compound elicitor was the causative agent of cell death.

Fractionation of the compound elicitor. We fractionated the compound elicitor by anion exchange chromatography using DEAE-Sepharose. The compound elicitor consisted of four fractions. First, we detected a polysaccharide from the unbound fraction (F1). After elution with $0.1 \mathrm{M} \mathrm{NaCl}$, SDS-PAGE revealed that a second fraction (F2) was a high-molecular-weight protein (>97 kDa). A third fraction (F3), eluted with $0.15 \mathrm{M} \mathrm{NaCl}$, was a broad-molecular-weight protein (66 to $97 \mathrm{kDa})$. The final fraction (F4), eluted with $0.3 \mathrm{M} \mathrm{NaCl}$, consisted of a smear-band protein and 45-kDa protein (Fig. 6A).

Identification of $F 1$ to $F 4$ fractions. SDS-PAGE did not indicate the presence of any protein in F1 (Fig. 6A). This result was supported by the FTIR analysis (Fig. 4B). Many of the absorption bands revealed by FTIR functional analysis $(3414,2921$, and 900 to $1200 \mathrm{~cm}^{-1}$ ) are characteristic of polysaccharides. Within and close to this range, IR bands near 1160, 1078, 1044, and $890 \mathrm{~cm}^{-1}$ are characteristic of fungal $(1 \rightarrow 3)(1 \rightarrow 6)-\beta$-D-glucans (Gutiérrez et al. 1996; Barth 2007) and absorption bands at 1155, 1023, 930, 850, and $765 \mathrm{~cm}^{-1}$ are characteristic of fungal $(1 \rightarrow 4)(1 \rightarrow 6)-\alpha-D$-glucans (Barth 2007). Since the FTIR spectrum of F1 showed absorption bands at 1158, 1074, 1042, and $892 \mathrm{~cm}^{-1}$ (Fig. 4B), we concluded that the F1 fraction was $(1 \rightarrow 3)(1 \rightarrow 6)-\beta$-D-glucan.

We stained each fraction with the periodic acid-Schiff (PAS) reagent after performing SDS-PAGE to detect glycoproteins (Zacharius et al. 1969). The F2 and F3 fractions gave positive bands with the PAS reagent (Fig. 6B), while F4 did not. The result demonstrated that F2 and F3 were glycoproteins.

Effects of each fraction. Cell death induction. At low concentration (1×) (Fig. 7A), only F3 caused cell death on tobacco leaves, while at high concentration $(5 \times)$ (Fig. 7B), every fraction except $\mathrm{F} 1$ caused cell death on tobacco leaves. The result suggested

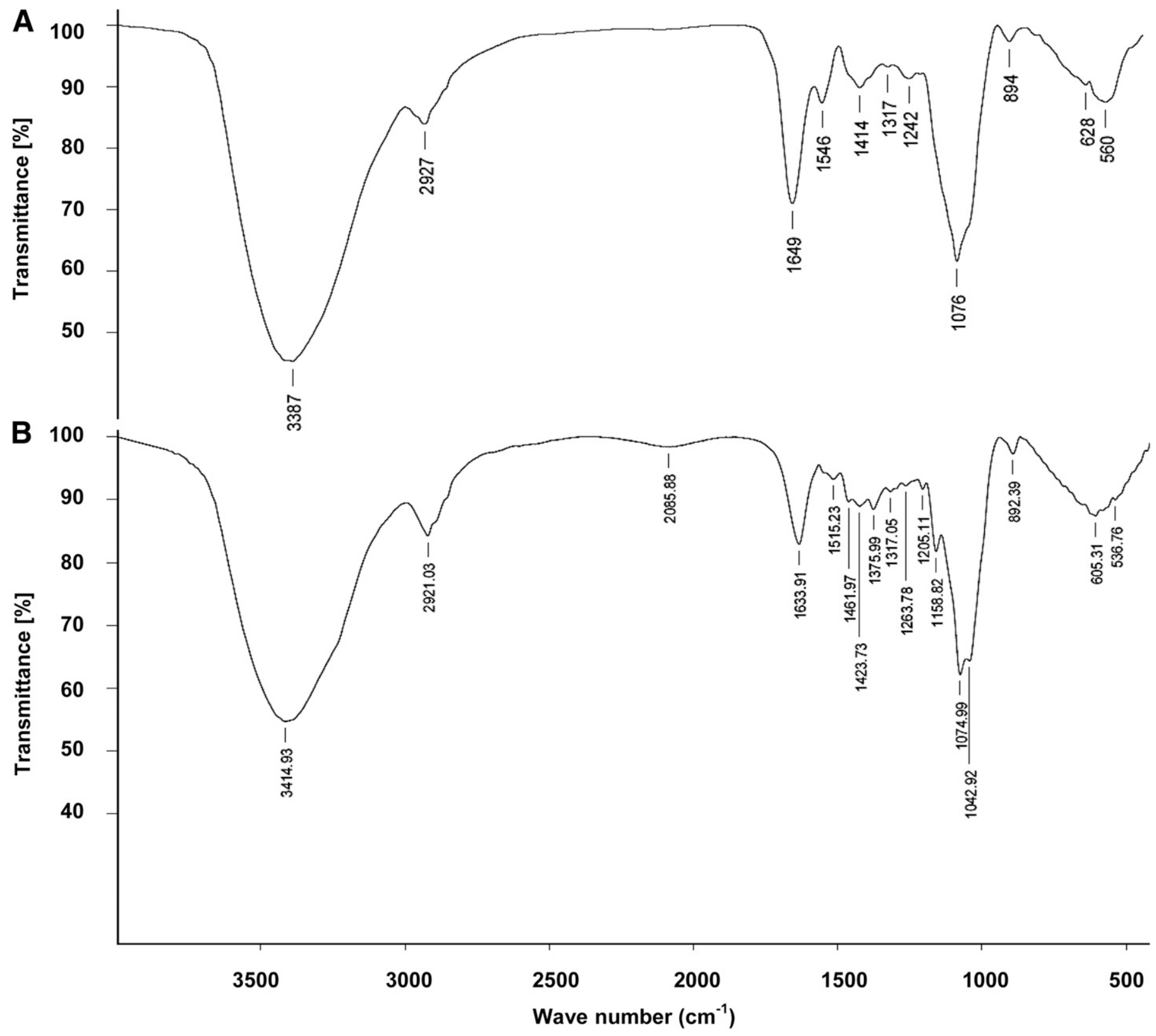

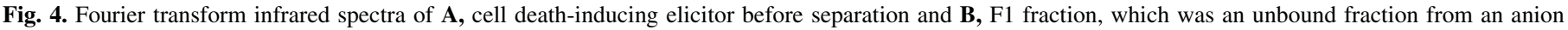
exchange column chromatography. 
that cell death was mainly caused by the broad-molecular-weight glycoprotein (F3) in the compound elicitor.

$S A$ and Scp accumulation. Each fraction was infiltrated into tobacco leaves and accumulations of SA and Scp were measured by HPLC. F2, F3, and F4 fractions, which had cell death-inducing activity, caused higher levels of SA accumulation than F1 (Fig. 7C). Similarly, Scp was induced in tobacco leaves treated by F2, F3, and F4 fractions (Fig. 7D). The results suggested that the cell death induction activity was correlated with the level of SA in leaves.

Promoting P. palmivora infection. Since F2, F3, and F4 could induce cell death, each fraction was cotreated with zoospores of $P$. palmivora. We found that $\mathrm{F} 2, \mathrm{~F} 3$, and F4 induced $P$. palmivora invasion that produced large infected areas (Fig. 8A and B). In contrast, rubber tree leaves coinfected with sterile distilled water or F1 showed small infected areas (Fig. 8B). Thus, the fractions that induced cell death and a high level of SA could promote $P$. palmivora infection on rubber tree leaves.

Further purification of F4 fraction. Since F4 mainly consisted of 45-kDa protein (Fig. 6A), it was further purified by size exclusion chromatography (Sephadex-G75). Each fraction eluted from the column was infiltrated into tobacco leaves to determine cell death activity. We found that fractions 37 to 39 were able to trigger cell death on tobacco leaves (Fig. 9A). Surprisingly, the mobility of the causative agent was shifted to $42 \mathrm{kDa}$ (Fig. 9B).

\section{DISCUSSION}

In this study, we isolated a new cell death-inducing elicitor from culture filtrate of $P$. palmivora by ethanol precipitation and deproteinization with Sevage reagent. The elicitor could induce cell death in tobacco leaves and chlorotic cell death in rubber tree leaves that had been wounded. The rubber tree leaf is covered with a thick cutin, it is not as easy to infiltrate as the tobacco leaf. Wounding could facilitate diffusion of the elicitor into rubber tree cells. Many cell death-inducing elicitors of Phytophthora spp. have been reported: INF1 from $P$. infestans (Kamoun et al. 1997), the 32$\mathrm{kDa}$ and 42-kDa glycoproteins from $P$. megasperma (Baillieul et al. 1995; Parker et al. 1991) and a glycoside hydrolase family 12 (GH12) protein from P. sojae (Ma et al. 2015).

In tobacco leaves infiltrated with the elicitor, $\mathrm{H}_{2} \mathrm{O}_{2}$ and $\mathrm{SA}$ accumulations were detected along with cell death (Figs. $1 \mathrm{C}$ and 2A). HR cell death requires the accumulation of $\mathrm{ROS}, \mathrm{O}_{2}^{-}$, and $\mathrm{H}_{2} \mathrm{O}_{2}$, which lead to an increase in levels of cytosolic $\mathrm{Ca}^{2+}$ and activation of the protein kinase-mediated cell death process (Levine et al. 1996; Mehdy 1994). Furthermore, the induction of cell death in plants is promoted by SA. Previous studies have elucidated the facilitation of cell death in plants by SA (Lu et al. 2009; Torres et al. 2005) and many works demonstrated induction of $\mathrm{H}_{2} \mathrm{O}_{2}$ and SA accumulations by cell death-inducing elicitors from Phytophthora spp. such as the 32-kDa glycoprotein from P. megasperma (Baillieul et al. 1995) and an oligopeptide of 13 amino acid (Pep-13) from P. sojae (Hahlbrock et al. 1995; Nürnberger et al. 1994). In the present study, the stress hormone ABA was significantly induced at $8 \mathrm{~h}$ posttreatment and remained at a high level through $12 \mathrm{~h}$ posttreatment (Fig. 2C). This behavior correlated to the occurrence of cell death stained with Trypan blue dye (Fig. 1C2). Cui et al. (2013) demonstrated that the spread of cell death caused by wounding is significantly induced by ABA. For our results, an increase of ABA might contribute to the expansion of cell death. Our crude elicitor also increased Scp accumulation in tobacco leaves (Fig. 2B). Other elicitors that caused Scp accumulation are 42-kDa glycoprotein from $P$. megasperma (Parker et al. 1991) and elicitin and a new protein, $75 \mathrm{kDa}$, from P. palmivora (Churngchow and Rattarasarn 2000; Dutsadee and Nunta 2008). As in tobacco
A

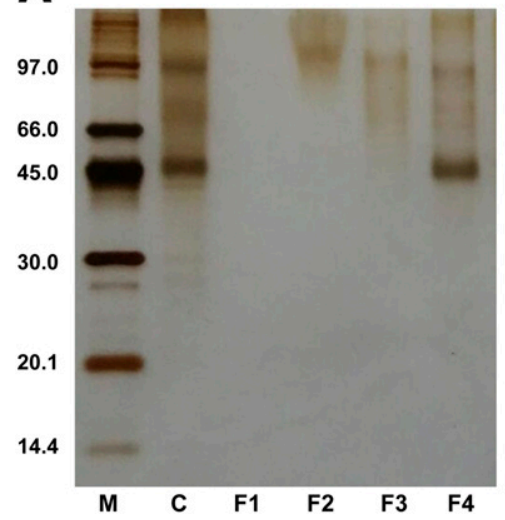

B

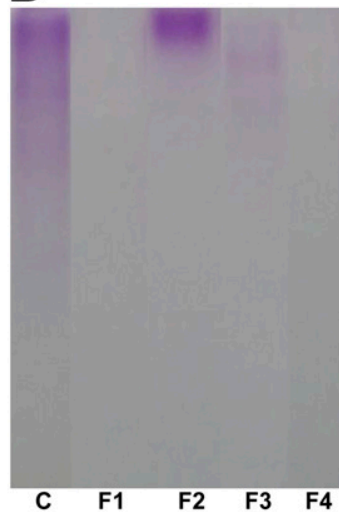

Fig. 6. Silver staining after A, sodium dodecyl sulfate-polyacrylamide gel electrophoresis and $\mathbf{B}$, periodic acid-Schiff staining of protein marker (lane $\mathrm{M}$ ), a crude elicitor (lane C), an unbound fraction (lane F1), a fraction eluted with $0.1 \mathrm{M} \mathrm{NaCl}$ (lane F2), a fraction eluted with $0.15 \mathrm{M} \mathrm{NaCl}$ (lane F3), and a fraction eluted with $0.3 \mathrm{M} \mathrm{NaCl}$ (lane F4) from anion exchange chromatography (DEAE-Sepharose).

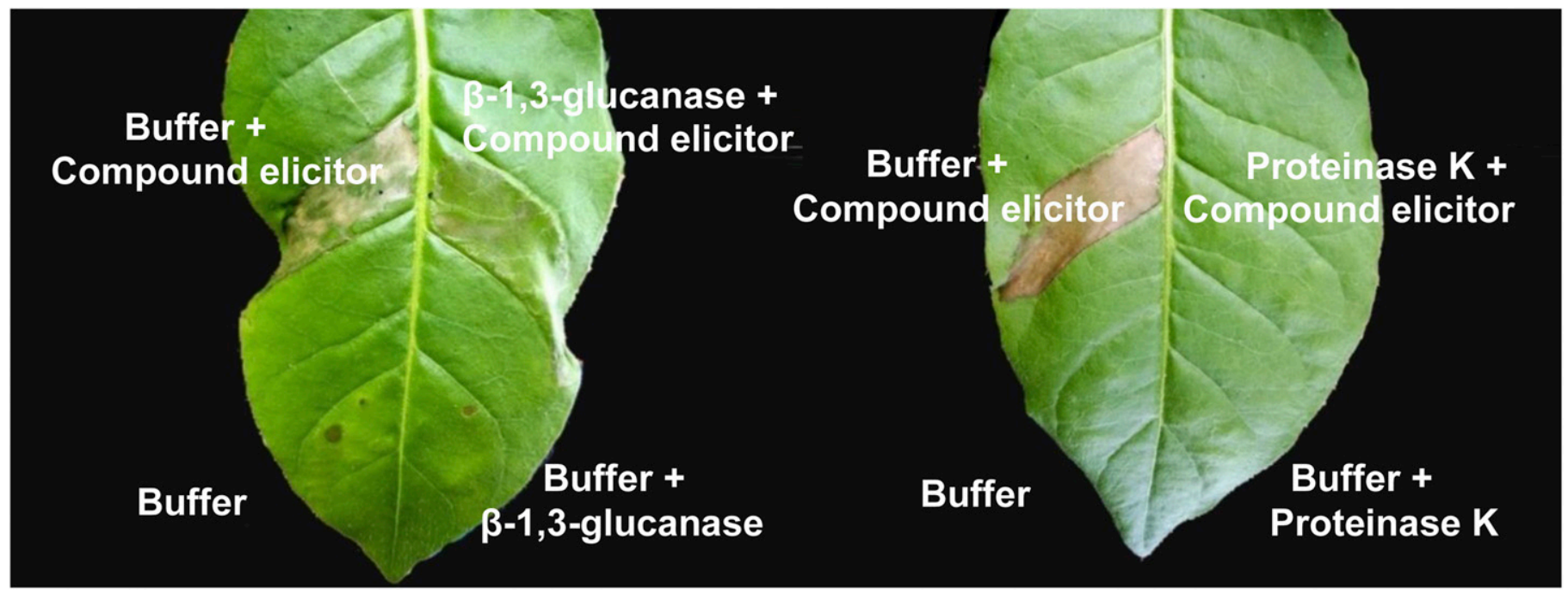

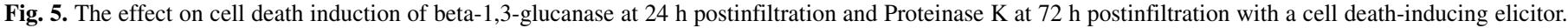
Images are representative of three independent biological replicates and all replicates showed the same results. 
leaves, SA, Scp, and ABA levels were increased in rubber tree leaves (Fig. 3A, B, and C).

Phytophthora pathogens are able to convert themselves into necrotrophs. Necrotrophic pathogens benefit from host cell death (Glazebrook 2005). As our hypothesis, elicitors that caused cell death and activated SA-signaling pathway could promote $P$. palmivora infection. We showed that the cell death-inducing elicitor promoted P. palmivora infection (Fig. 3D and F). Various low-molecular-weight phytotoxic metabolites are produced by necrotrophic pathogens (van Kan 2006) and many phytotoxic proteins induced necrosis in plants (Choquer et al. 2007). B. cinerea, a necrotrophic pathogen, promotes its infection by producing a lytic enzyme and maintaining high levels of ROS, toxins, and necrosisinducing factors (Choquer et al. 2007; van Kan 2006). The oomycete hemibiotrophic pathogen, $P$. sojae, produces a glycoside hydrolase family 12 (GH12) protein, which induces cell death in $N$. benthamiana and plays as an important virulence factor during P. sojae infection (Ma et al. 2015). When P. palmivora entered the necrotrophic phase in our experiment, the cell death-inducing elicitor could promote its infection (Fig. 3D and F).

Plants have many pathogenesis-related (PR) proteins. These proteins have been classified into 17 families according to their properties and functions (van Loon et al. 2006). Many of them, such as PR2 (beta-1,3-glucanases), PR3 (chitinases), and PR7 (endoproteases), have a hydrolytic property. These enzymes are secreted into intercellular spaces where recognition and signaling activation processes occur (Dixon and Lamb 1990; van Loon et al. 2006). We found that beta-1,3-glucanase did not inhibit the appearance of cell death but on the other hand, Proteinase K, a serine protease, completely neutralized the effect of the cell death-inducing elicitor (Fig. 5). Therefore, we concluded that the causative agent in the compound elicitor was a protein. During natural infection of rubber tree leaves by $P$. palmivora, only $H b S P A$, a subtilisin-like serine protease gene, is induced at the early stage of infection, later returning to a low level. But other subtilisin-like serine protease genes, $H b S P B$ and $H b S P C$, are significantly suppressed throughout infection (Ekchaweng et al. 2017). During infection by P. palmivora, rubber tree leaves have a low amount of cell death neutralizers, so cell death elicitors can strongly exhibit their activity. Thus, a rubber

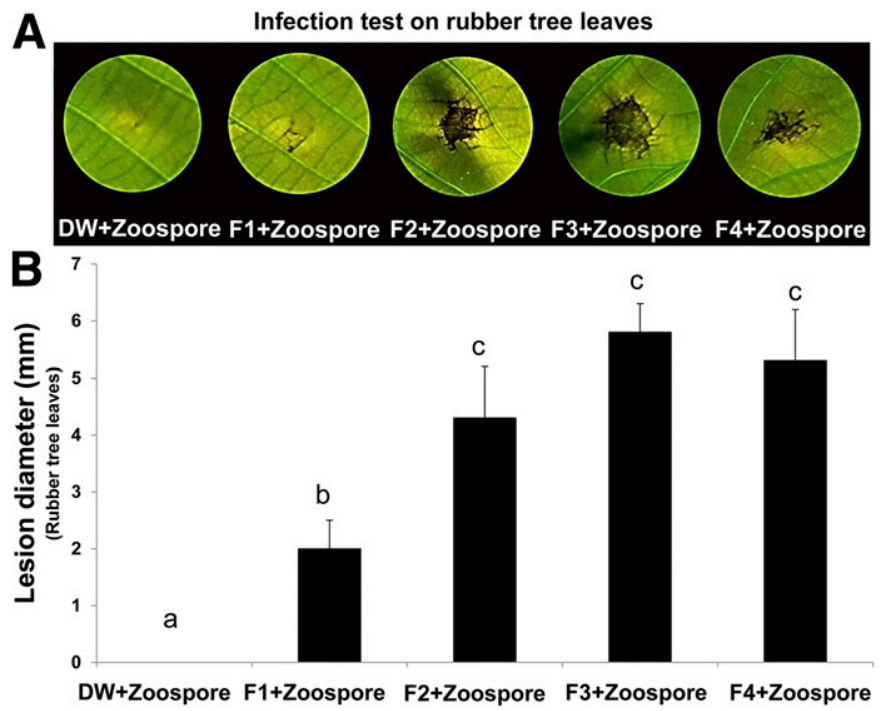

Fig. 8. A, The representative rubber tree leaves after cotreatment with each fraction and zoospores of Phytophthora palmivora at 5 days after treatment. B, Lesion diameter $(\mathrm{mm})$ of rubber tree leaves cotreated with each fraction and zoospores of $P$. palmivora at 5 days after treatment. Data bars are the means $( \pm \mathrm{SE})$ of four independent biological replicates. Significant differences according to Duncan's multiple range test $(P \leq 0.05)$ were presented by differences among treatments.

\section{A}

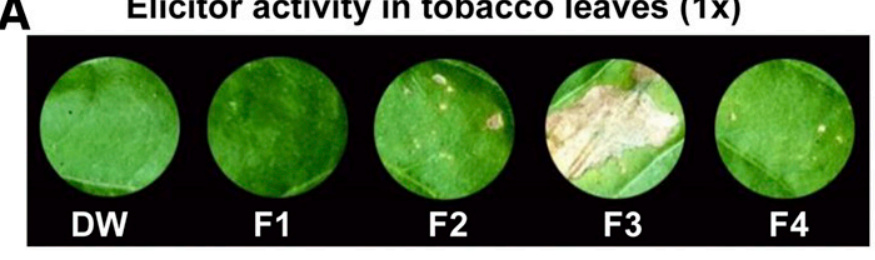

C

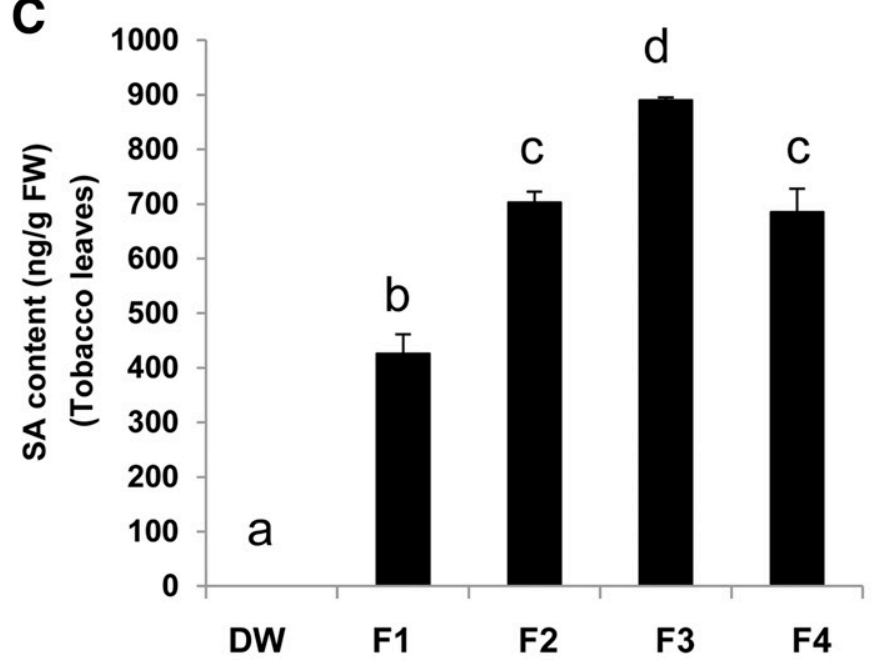

B

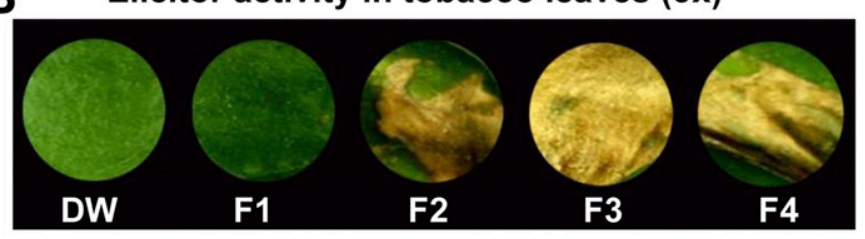

D

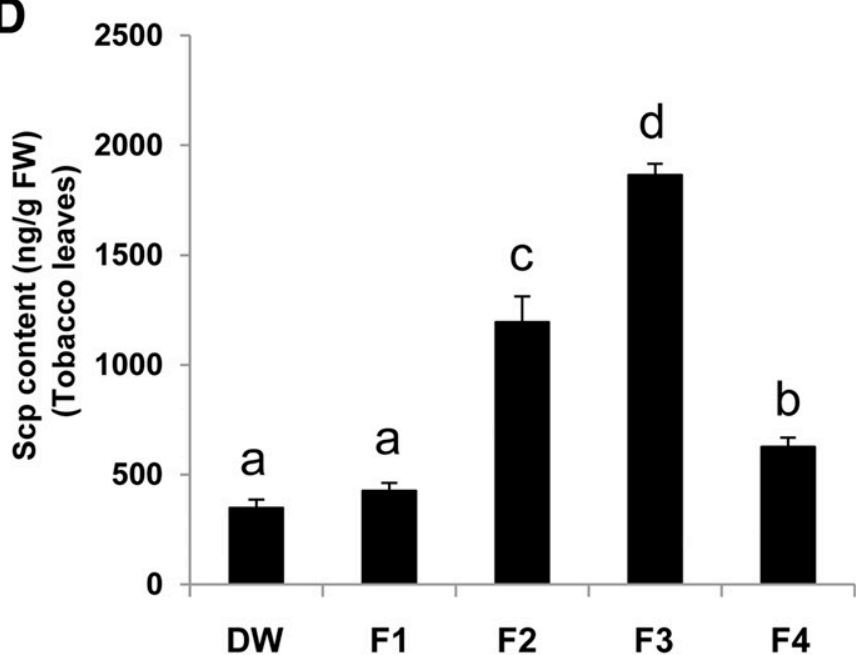

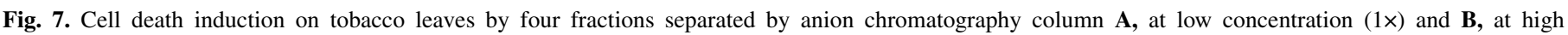

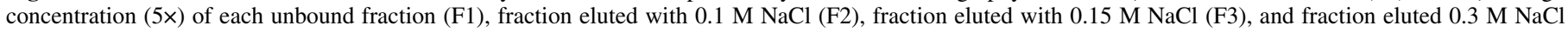

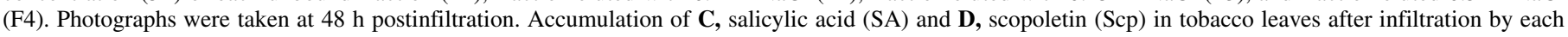

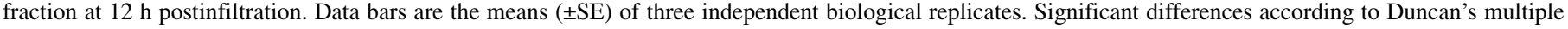
range test $(P \leq 0.05)$ were presented by differences among treatments. 
plant that could overexpress protease should be more resistant than the control plants.

After fractionation, we found that the unbound fraction $(\mathrm{F} 1)$ was beta-1,3-glucan (Fig. 4B). This finding is correlated with the fact that the cell wall of oomycetes mainly consists of beta-1,3-glucan. Linear beta-1,3-glucan extracted from the brown alga, Laminaria digitata, was shown as an elicitor that induced defense responses in tobacco (Klarzynski et al. 2000) and a pure glucan extracted from mycelium wall of $P$. megasperma induced the synthesis of phytoalexins in soybean (Sharp et al. 1984). In this study, we successfully purified exo-beta-1,3-glucan from culture filtrate of $P$. palmivora. After eluting the column with $\mathrm{NaCl}$, we obtained a high-molecular-weight glycoprotein (F2), a broad-molecularweight glycoprotein (F3), and a fraction that mainly consisted of the 45-kDa protein (F4) (Fig. 6B). Phytophthora spp. produce many glycoproteins. The $34-\mathrm{kDa}$ glycoprotein elicitor (CBEL) produced by $P$. parasitica is localized in the cell wall (Gaulin et al. 2006; Mateos et al. 1997) and an oligopeptide of 13 amino acid (Pep-13) is identified within the cell wall glycoprotein (GP42) of P. sojae (Brunner et al. 2002; Hahlbrock et al. 1995; Nürnberger et al. 1994).

The beta-glucan, F1 fraction, did not cause cell death on tobacco leaves at high or low concentration (Fig. 7A and B). This result was similar to the result of Klarzynski et al. (2000) who illustrated that laminarin, a linear beta-1,3-glucan could not induce cell death on tobacco leaves. On the other hand, fractions F2, F3, and F4 did induce cell death on tobacco leaves (Fig. 7A and B). The highmolecular-weight glycoprotein fraction was previously identified by Parker et al. (1991), who studied the extracellular glycoprotein from $P$. megasperma without identifying its effects. We showed that the high-molecular-weight glycoprotein from $P$. palmivora could cause cell death on tobacco leaves (Fig. 7B).

Previous researches elucidated that SA facilitates cell death on plants (Lu et al. 2009; Torres et al. 2005). Not only cell deathinducing fractions, but beta-glucan also induced the accumulation of SA (Fig. 7C). Similarly, a linear beta-glucan from brown alga and

\section{A Fraction No.}

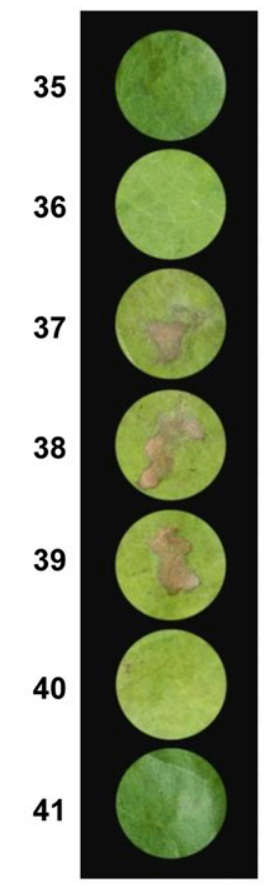

\section{(Tobacco leaves)}

Fig. 9. Purification of the F4 fraction by size exclusion chromatography (Sephadex G-75): A, the fractions that possess cell death-inducing activity and B, silver staining after sodium dodecyl sulfate-polyacrylamide gel electrophoresis of pooled cell death-inducing fractions. beta-glucan produced by $B$. cinerea stimulate SA accumulation in plants (El Oirdi et al. 2011; Klarzynski et al. 2000). Interestingly, the fraction that caused larger areas of cell death induced higher levels of SA (Fig. 7C). Fu et al. (2012) explained why high SA levels can cause cell death in plants: the level of SA affected NPR3 and NPR4, the cullin 3 (CUL3) adapters for degradation of NPR1 (a cell death suppressor). At high concentrations, SA binds to NPR3 and mediates the degradation of NPR1, which induces cell death. But at low concentrations, SA cannot bind to NPR3 and connects instead to NPR4, which blocks NPR1 degradation, resulting in cell survival.

As we expected, all cell death-inducing fractions (F2, F3, and F4) promoted P. palmivora infection (Fig. 8). Govrin and Levine (2000) suggested that the HR cell death resists biotrophic infection by disconnecting nutrient supplies and limiting pathogen growth. However, by doing so, it may provide growth substrates for invasive necrotrophs. Hemibiotrophs kill the host cell and switch to the necrotrophic fungal phase after establishment of the biotrophic stage within the plant cell (Horbach et al. 2011). PCD effectively inhibits biotrophic pathogens that are regulated by the SAdependent pathway. On the other hand, necrotrophic pathogens benefiting from the host cell death are not restricted by the SAdependent pathway and cell death but are controlled by the JAsignaling pathway (Glazebrook 2005). The effects of many cell death-inducing elicitors from various pathogens have been reported. An XEG1 elicitor produced by the soybean pathogen $P$. sojae is an important virulence factor during $P$. sojae infection (Ma et al. 2015). An elicitor isolated from the intercellular fluid of $A$. thaliana leaves infected with $B$. cinerea induces cell death. After infiltration with this elicitor prior to inoculation with spores of $B$. cinerea, it promotes $B$. cinerea infection by increasing lesion size (Govrin et al. 2006). Dead cells caused from hypersensitive response make the plants resistant to the biotrophs, but if plants are infected by necrotrophs in the same area, the infection can spread. So, the prior activation of cell death caused by biotrophic pathogens can further promote necrotrophic pathogen infection (Kliebenstein and Rowe 2008). As P. palmivora is a hemibiotroph, our study showed that cell death-inducing elicitors promote its infection of rubber tree leaves. After coinfection with cell deathinducing elicitors, cell death effects did not completely inhibit $P$. palmivora infection at the early, biotrophic phase. Conversely, in the later, necrotrophic phase, they promoted P. palmivora infection. We propose that the activation of ROS and SA by $P$. palmivora that causes cell death also promotes its infection in the necrotrophic phase. In a cell death area, $P$. palmivora is separated from living cells, thanks to its lifecycle, it can survive and wait to spread later.

After purifying the F4 fraction with Sephadex G-75, we obtained a 42-kDa elicitor that caused cell death (Fig. 9B). This $42-\mathrm{kDa}$ elicitor appeared as $45 \mathrm{kDa}$ in the F4 fraction (Fig. 6A). Rath et al. (2009) showed that gel shifting in SDS-PAGE is influenced by SDS binding capacity. The purification of the 42-kDa elicitor eliminated many molecules that interfered with SDS binding, therefore providing more charge for the target protein to move in the PAGE.

\section{LITERATURE CITED}

Baillieul, F., Genetet, I., Kopp, M., Saindrenan, P., Fritig, B., and Kauffmann, S. 1995. A new elicitor of the hypersensitive response in tobacco: A fungal glycoprotein elicits cell death, expression of defence genes, production of salicylic acid, and induction of systemic acquired resistance. Plant J. 8: 551-560.

Barth, A. 2007. Infrared spectroscopy of proteins. Biochim. Biophys. ActaBioenerg. 1767:1073-1101.

Belton, P. S., Colquhoun, I. J., Grant, A., Wellner, N., Field, J. M., Shewry, P. R., and Tatham, A. S. 1995. FTIR and NMR studies on the hydration of a high- $M_{\mathrm{r}}$ subunit of glutenin. Int. J. Biol. Macromol. 17:74-80.

Bent, A. F., and Mackey, D. 2007. Elicitors, effectors, and $R$ genes: The new paradigm and a lifetime supply of questions. Annu. Rev. Phytopathol. 45: 399-436.

Brooks, D. M., Bender, C. L., and Kunkel, B. N. 2005. The Pseudomonas syringae phytotoxin coronatine promotes virulence by overcoming salicylic 
acid-dependent defences in Arabidopsis thaliana. Mol. Plant Pathol. 6: 629-639.

Brunner, F., Rosahl, S., Lee, J., Rudd, J. J., Geiler, C., Kauppinen, S., et al. 2002. Pep-13, a plant defense-inducing pathogen-associated pattern from Phytophthora transglutaminases. EMBO J. 21:6681-6688.

Chang, Y. H., Yan, H. Z., and Liou, R. F. 2015. A novel elicitor protein from Phytophthora parasitica induces plant basal immunity and systemic acquired resistance. Mol. Plant Pathol. 16:123-136.

Choquer, M., Fournier, E., Kunz, C., Levis, C., Pradier, J. M., Simon, A., et al. 2007. Botrytis cinerea virulence factors: New insights into a necrotrophic and polyphageous pathogen. FEMS Microbiol. Lett. 277:1-10.

Churngchow, N., and Rattarasarn, M. 2000. The elicitin secreted by Phytophthora palmivora, a rubber tree pathogen. Phytochemistry 54:33-38.

Cui, F., Brosché, M., Sipari, N., Tang, S., and Overmyer, K. 2013. Regulation of ABA dependent wound induced spreading cell death by MYB108. New Phytol. 200:634-640.

Cui, J., Bahrami, A. K., Pringle, E. G., Hernandez-Guzman, G., Bender, C. L., Pierce, N. E., et al. 2005. Pseudomonas syringae manipulates systemic plant defenses against pathogens and herbivores. Proc. Natl. Acad. Sci. 102: 1791-1796.

Dixon, R. A., and Lamb, C. J. 1990. Molecular communication in interactions between plants and microbial pathogens. Annu. Rev. Plant Physiol. Plant Mol. Biol. 41:339-367.

Dutsadee, C., and Nunta, C. 2008. Induction of peroxidase, scopoletin, phenolic compounds and resistance in Hevea brasiliensis by elicitin and a novel protein elicitor purified from Phytophthora palmivora. Physiol. Mol. Plant Pathol. 72:179-187.

Ederli, L., Madeo, L., Calderini, O., Gehring, C., Moretti, C., Buonaurio, R., et al. 2011. The Arabidopsis thaliana cysteine-rich receptor-like kinase CRK20 modulates host responses to Pseudomonas syringae pv. tomato DC3000 infection. J. Plant Physiol. 168:1784-1794.

Ekchaweng, K., Khunjan, U., and Churngchow, N. 2017. Molecular cloning and characterization of three novel subtilisin-like serine protease genes from Hevea brasiliensis. Physiol. Mol. Plant Pathol. 97:79-95.

El Oirdi, M., El Rahman, T. A., Rigano, L., El Hadrami, A., Rodriguez, M. C., Daayf, F., et al. 2011. Botrytis cinerea manipulates the antagonistic effects between immune pathways to promote disease development in tomato. Plant Cell 23:2405-2421.

Fu, Z. Q., Yan, S., Saleh, A., Wang, W., Ruble, J., Oka, N., et al. 2012. NPR3 and NPR4 are receptors for the immune signal salicylic acid in plants. Nature 486:228-232.

Gaulin, E., Dramé, N., Lafitte, C., Torto-Alalibo, T., Martinez, Y., Ameline-Torregrosa, C., et al. 2006. Cellulose binding domains of a Phytophthora cell wall protein are novel pathogen-associated molecular patterns. Plant Cell 18:1766-1777.

Glazebrook, J. 2005. Contrasting mechanisms of defense against biotrophic and necrotrophic pathogens. Annu. Rev. Phytopathol. 43:205-227.

Govrin, E. M., and Levine, A. 2000. The hypersensitive response facilitates plant infection by the necrotrophic pathogen Botrytis cinerea. Curr. Biol. 10:751-757.

Govrin, E. M., Rachmilevitch, S., Tiwari, B. S., Solomon, M., and Levine, A. 2006. An elicitor from Botrytis cinerea induces the hypersensitive response in Arabidopsis thaliana and other plants and promotes the gray mold disease. Phytopathology 96:299-307.

Gutiérrez, A., Prieto, A., and Martínez, A. T. 1996. Structural characterization of extracellular polysaccharides produced by fungi from the genus Pleurotus. Carbohydr. Res. 281:143-154.

Hahlbrock, K., Scheel, D., Logemann, E., Nurnberger, T., Parniske, M., Reinold, S., et al. 1995. Oligopeptide elicitor-mediated defense gene activation in cultured parsley cells. Proc. Natl. Acad. Sci. 92:4150-4157.

Henniger, H. 1963. Zur Kultur von Phytophthora infestans auf vollsynthetischen Nährsubstraten. Z. Allg. Mikrobiol. 3:126-135.

Horbach, R., Navarro-Quesada, A. R., Knogge, W., and Deising, H. B. 2011. When and how to kill a plant cell: Infection strategies of plant pathogenic fungi. J. Plant Physiol. 168:51-62.

Kamoun, S., Van West, P., De Jong, A. J., De Groot, K. E., Vleeshouwers, V. G. A. A., and Govers, F. 1997. A gene encoding a protein elicitor of Phytophthora infestans is down-regulated during infection of potato. Mol. Plant-Microbe Interact. 10:13-20.

Klarzynski, O., Plesse, B., Joubert, J.-M., Yvin, J.-C., Kopp, M., Kloareg, B., et al. 2000. Linear $\beta$-1,3-glucans are elicitors of defense responses in tobacco. Plant Physiol. 124:1027-1038.

Kliebenstein, D. J., and Rowe, H. C. 2008. Ecological costs of biotrophic versus necrotrophic pathogen resistance, the hypersensitive response and signal transduction. Plant Sci. 174:551-556.
Koornneef, A., Leon-Reyes, A., Ritsema, T., Verhage, A., Den Otter, F. C., Van Loon, L. C., et al. 2008. Kinetics of salicylate-mediated suppression of jasmonate signaling reveal a role for redox modulation. Plant Physiol. 147: 1358-1368.

Latijnhouwers, M., De Wit, P. J. G. M., and Govers, F. 2003. Oomycetes and fungi: Similar weaponry to attack plants. Trends Microbiol. 11:462-469.

Lee, S. J., and Rose, J. K. C. 2010. Mediation of the transition from biotrophy to necrotrophy in hemibiotrophic plant pathogens by secreted effector proteins. Plant Signal. Behav. 5:769-772.

Leite, M., Quinta-Costa, M., Leite, P. S., and Guimarães, J. E. 1999. Critical evaluation of techniques to detect and measure cell death study in a model of UV radiation of the leukaemic cell line HL60. Anal. Cell. Pathol. 19: 139-151.

Levine, A., Pennell, R. I., Alvarez, M. E., Palmer, R., and Lamb, C. 1996. Calcium-mediated apoptosis in a plant hypersensitive disease resistance response. Curr. Biol. 6:427-437.

Lu, H., Salimian, S., Gamelin, E., Wang, G., Fedorowski, J., Lacourse, W., et al. 2009. Genetic analysis of acd6-1 reveals complex defense networks and leads to identification of novel defense genes in Arabidopsis. Plant J. 58:401-412.

Ma, Z., Song, T., Zhu, L., Ye, W., Wang, Y., Shao, Y., et al. 2015. A Phytophthora sojae glycoside hydrolase 12 protein is a major virulence factor during soybean infection and is recognized as a PAMP. Plant Cell 27: 2057-2072.

Mateos, F. V., Rickauer, M., and Esquerré-Tugayé, M. T. 1997. Cloning and characterization of a cDNA encoding an elicitor of Phytophthora parasitica var. nicotianae that shows cellulose-binding and lectin-like activities. Mol. Plant-Microbe Interact. 10:1045-1053.

Mehdy, M. 1994. Active oxygen species in plant defense against pathogens. Plant Physiol. 105:467-472.

Nürnberger, T., Nennstiel, D., Jabs, T., Sacks, W. R., Hahlbrock, K., and Scheel, D. 1994. High affinity binding of a fungal oligopeptide elicitor to parsley plasma membranes triggers multiple defense responses. Cell 78: 449-460.

Parker, J. E., Schulte, W., Hahlbrock, K., and Scheel, D. 1991. An extracellular glycoprotein from Phytophthora megasperma f. sp. glycinea elicits phytoalexin synthesis in cultured parsley cells and protoplasts. Mol. PlantMicrobe Interact. 4:19-27.

Pieterse, C. M. J., Van der Does, D., Zamioudis, C., Leon-Reyes, A., and Van Wees, S. C. M. 2012. Hormonal modulation of plant immunity. Annu. Rev. Cell Dev. Biol. 28:489-521.

Rath, A., Glibowicka, M., Nadeau, V. G., Chen, G., and Deber, C. M. 2009. Detergent binding explains anomalous SDS-PAGE migration of membrane proteins. Proc. Natl. Acad. Sci. 106:1760-1765.

Šandula, J., Kogan, G., Kačuráková, M., and MacHová, E. 1999. Microbial $(1 \rightarrow 3)-\beta$-D-glucans, their preparation, physico-chemical characterization and immunomodulatory activity. Carbohydr. Polym. 38:247-253.

Sharp, J. K., Valent, B., and Albersheim, P. 1984. Purification and partial characterization of a beta-glucan fragment that elicits phytoalexin accumulation in soybean. J. Biol. Chem. 259:11312-11320.

Spoel, S. H., Johnson, J. S., and Dong, X. 2007. Regulation of tradeoffs between plant defenses against pathogens with different lifestyles. Proc. Natl. Acad. Sci. 104:18842-18847.

Thordal-Christensen, H., Zhang, Z., Wei, Y., and Collinge, D. B. 1997. Subcellular localization of $\mathrm{H}_{2} \mathrm{O}_{2}$ in plants. $\mathrm{H}_{2} \mathrm{O}_{2}$ accumulation in papillae and hypersensitive response during the barley-powdery mildew interaction. Plant J. 11:1187-1194.

Torres, M. A., Jones, J. D. G., and Dangl, J. L. 2005. Pathogen-induced, NADPH oxidase-derived reactive oxygen intermediates suppress spread of cell death in Arabidopsis thaliana. Nat. Genet. 37:1130-1134.

van Kan, J. A. L. 2006. Licensed to kill: The lifestyle of a necrotrophic plant pathogen. Trends Plant Sci. 11:247-253.

van Loon, L. C., Rep, M., and Pieterse, C. M. J. 2006. Significance of inducible defense-related proteins in infected plants. Annu. Rev. Phytopathol. 44:135-162.

Werner, S., Steiner, U., Becher, R., Kortekamp, A., Zyprian, E., and Deising, H. B. 2002. Chitin synthesis during in planta growth and asexual propagation of the cellulosic oomycete and obligate biotrophic grapevine pathogen Plasmopara viticola. FEMS Microbiol. Lett. 208:169-173.

Yang, X., Kang, L., and Tien, P. 1996. Resistance of tomato infected with cucumber mosaic virus satellite RNA to potato spindle tuber viroid. Ann. Appl. Biol. 129:543-551.

Zacharius, R. M., Zell, T. E., Morrison, J. H., and Woodlock, J. J. 1969. Glycoprotein staining following electrophoresis on acrylamide gels. Anal. Biochem. 30:148-152. 